\title{
THE EFFECT OF ARSENIC ON THE THERMAL TOLERANCE AND SURVIVAL OF NEWLY HATCHED MUSKELLUNGE FRY (ESOX MASQUINONGY)
}

\section{$\overline{\text { THESIS }}$}

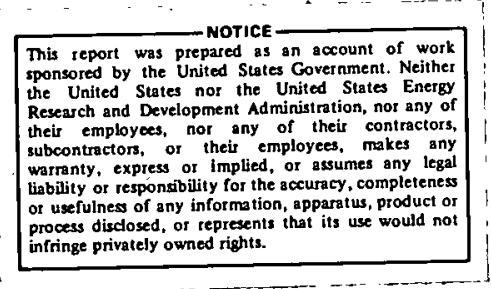

A thesis submitted in partial fulfillment of the requirements for the degree of Master of Arts of the State University College at Buffalo.

By

Frank V. Paladino

Buffalo, New York

Director: Dr: James R. Spotila

Assistant Professor of Biology

Buffalo, New York 


\section{DISCLAIMER}

This report was prepared as an account of work sponsored by an agency of the United States Government. Neither the United States Government nor any agency Thereof, nor any of their employees, makes any warranty, express or implied, or assumes any legal liability or responsibility for the accuracy, completeness, or usefulness of any information, apparatus, product, or process disclosed, or represents that its use would not infringe privately owned rights. Reference herein to any specific commercial product, process, or service by trade name, trademark, manufacturer, or otherwise does not necessarily constitute or imply its endorsement, recommendation, or favoring by the United States Government or any agency thereof. The views and opinions of authors expressed herein do not necessarily state or reflect those of the United States Government or any agency thereof. 


\section{DISCLAIMER}

Portions of this document may be illegible in electronic image products. Images are produced from the best available original document. 
ABSTRACT OF THESIS

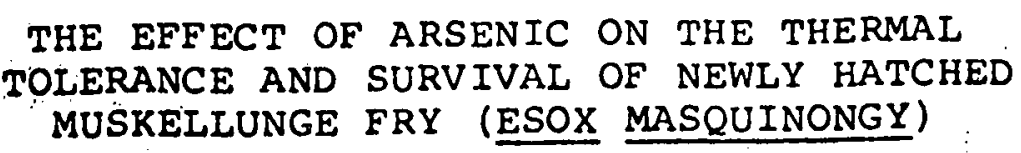

Newly hatched muskellunge fry were raised in tanks containing $0.00,0.05,1.0$ and $5.0 \mathrm{ppm}$ arsenic as sodium arsenite $\left(\mathrm{NaAsO}_{2}\right)$ at a temperature of $15^{\circ} \mathrm{C}\left( \pm 0.5^{\circ} \mathrm{C}\right)$ and a photoperiod of 12 hours of light alternating with 12 hours of dark (L. D. 12 : 12). Dissolved oxygen, alkalinity, pH, and ammonia ranged between $8.0-10.5 \mathrm{mg} I^{-1} 0_{2}, 149-190 \mathrm{mg} \mathrm{I}{ }^{-1} \mathrm{CaCO}_{3}, 7.2-7.7$ and $.05 \mathrm{mg} \mathrm{I}^{-1} \mathrm{NH}_{4}$ respectively.

Temperature tolerance of fry, Critical Thermal Maximum, (CTM), was significantly reduced by exposure to arsenic ( $P=0.05)$.

Fry raised at arsenic concentrations of $0.05 \mathrm{ppm}$ or greater suffered 1008 mortality during or shortly after swim-up. Control (0.00 ppm) fry had a sharp drop in CTM during swim-up, became active feeders and continued to develop normally. Fraank V. Paladine

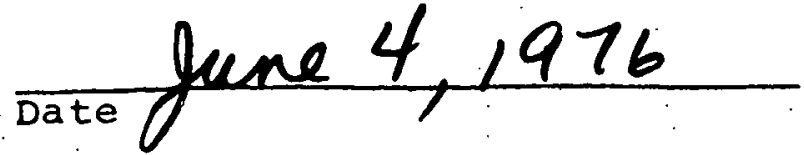


TABLE OF CONTENTS

PAGE

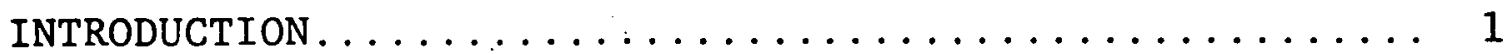

METHODS AND MATERIALS $\ldots \ldots \ldots \ldots \ldots \ldots \ldots \ldots \ldots \ldots$

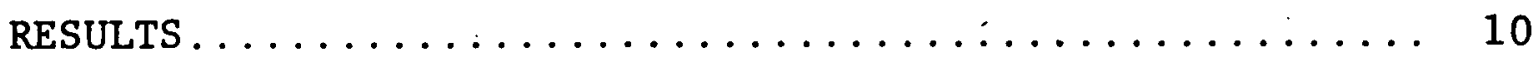

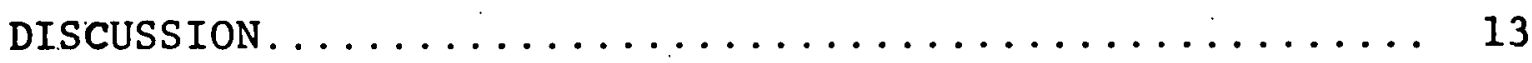

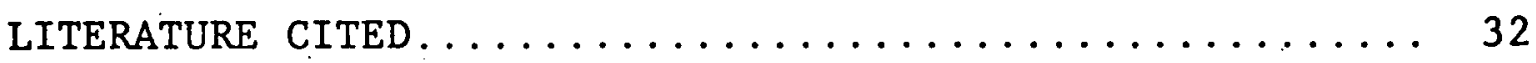

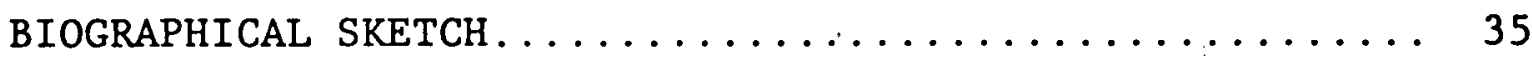




\section{LIST OF TABLES}

Tables

Page

1. Classification of elements according to their .16 toxicity, after Wood (1974).

2. Water quality for the experimental tanks used

in the arsenic study. Values are given as ranges.

3. One Way ANOVA for overall CTM of muskellunge 18

fry reared in 0.00 (Contro1), $0.05,1.0$, and

$5.0 \mathrm{ppm}$ arsenic.

4. One Way ANOVA for CTM of muskellunge fry reared 18 in 0.00 (Control) and $0.05 \mathrm{ppm}$ arsenic.

5. One Way ANOVA for CTM through time of muskellunge 19 fry reared in $0.00 \mathrm{ppm}$ (Control).

6. One Way ANOVA for CTM through time of muskellunge .19 fry reared in $0.05 \mathrm{ppm}$ arsenic.

7. One Way ANOVA for CTM through time of muskellunge .20 fry reared in $1.0 \mathrm{ppm}$ arsenic.

8. One Way ANOVA for CTM throug-time of muskellunge .20 fry reared in $5.0 \mathrm{ppm}$ arsenic. 


\section{LIST OF ILLUSTRATIONS}

Figure

Page

1. Outline map of Chautauqua Lake, New York.

2. The biological cycle for arsenic redrawn after Wood (1974).

3. Graphical comparison of the overall CTM (mean \pm 2 S.E.) for muskellunge fry reared in 0.00 (Control): $0.05,1.0$ and $5.0 \mathrm{ppm}$ arsenic.

4. CTM through time of muskellunge fry reared in $0.00 \mathrm{ppm}$ arsenic (Contro1).

5. CTM through time of muskellunge fry reared in 0.05 ppm arsenic.

6. CTM through time of muskellunge fry reared in $1.0 \mathrm{ppm}$ arsenic.

7. CTM through time of muskellunge fry reared in 5.0 ppm arsenic.

8. Daily mortality (percent dead) through time of 28
muskellunge fry reared in $0.00 \mathrm{ppm}$ arsenic (Control)

9. Daily mortality (percent dead) through time of 29 muskellunge fry reared in $0.05 \mathrm{ppm}$ arsenic.

10. Daily mortality (percent dead) through time of 30 muskellunge fry reared in $1.0 \mathrm{ppm}$ arsenic.

11. Daily mortality (percent dead) through time of 31 muskellunge fry reared in $5.0 \mathrm{ppm}$ arsenic. 


\section{INTRODUCTION}

Industrial waste disposal methods and pesticide application practices have introduced high concentrations of many heavy metals into aquatic ecosystems. Numerous publications have described the effects of heavy metals, such as arsenic, cadmium, copper, lead, selenium, tin, zinc and especially mercury on the physiology and survival of fish (Surber 1932, Hart et al. 1945, Douderoff et al. 1951, Lawrence 1958, 1962, 1966, Cairns and Schnierer 1957, 1959, 1964, Dupree 1960, McKee and Wolf 1963, Johnson 1968, Uthe and Bligh 1971, Wood 1974, Cairns et al. 1975).

A review of the available literature resulted in limited and conflicting information on the effects of heavy metals on immature fish. The majority of fish toxicity studies have been conducted using adult indicator organisms such as bluegill sunfish, (Lepomis macrochirus) and smallmouth bass, (Micropterous dolomieuil) A few studies indirectly. indicated that developing fish were more susceptible to heavy metal pollution than were adults (Gilderhaus 1966, Hiltebran 1967, Nimi and LaHam 1975).

Cairns and Schnierer $(1957,1959)$ described how pH, temperature, and alkalinity affected the toxicity of zinc to adult $\underline{L}$. macrochirus. To my knowledge no research has been conducted to determine the effect of a heavy metal on the thermal tolerance of a developing fish. Some studies have indicated that developing immature fish have a lower temperature tolerance than their eggs and adults (Brett 1956, Banner and Van Arman 1973, Hokanson et al. 1973) . Hassan and spotila (1976), found that rearing temper- 
ature affected the thermal tolerance of developing muskellunge fry (Esox masquinongy). They postulated that rearing temperatures and other parameters such as heavy metal contamination of the hatchery water might be contributing to the large scale mortalities of fry at the New York state muskellunge hatchery on Chautauqua Lake.

Chautauqua Lake is located in Chautauqua county at the far western part of New York State. It is finger like in shape, oriented in $\dot{a}$ north-south direction with a length of $27 \mathrm{~km}$ and a width that varies from 1 to $3 \mathrm{~km}$ (Fig. 1). The New York State Department of Environmental Conservation established a hatchery in 1964, at Pendergast Point, in order to raise muskellunge (Esox masquinongy) to fingerling size $(12-20 \mathrm{~cm})$ for stocking. Numerous die-offs have occurred at the hatchery, with $100 \%$ mortalities occurring in seven of the last ten years (Youmans 1974). The reason for these die-offs has not been determined.

Chautauqua Lake waters have a past history of high arsenic levels (Ullman et al. 1961). In a recent study Lis and Hopke (1973) found arsenic in the lake waters ranging up to $43.3 \mathrm{ppla}$. In a later study Hopke et al. (1974) found that arsenic concentrations in lake sediments ranged from 0.5 to $300 \mathrm{ppm}$, with an overall average of $22.1 \mathrm{ppm}$. They stated that the sediments of the lake have higher arsenic values than the natural sources in the surrounding area. They attributed these higher concentrations of arsenic to the use of sodium arsenite as an aquatic herbicide during the period 1955 to 1964. During the 1960's arsenic was found in high concentrations in Chautauqua Lake waters. Since the lake is a 
public drinking water source, the New York State Department of Health banned the further use of the aquatic herbicide, sodium arsenite, in the lake (Nicholson 1974).

I conducted a preliminary atomic absorption spectrophotometric analysis of the well water from the Pendergast Point Hatchery and found the concentration of arsenic was 3.52 times greater than the New York State Department of Health recommends for drinking water. The concentrations of all other metals tested were within the normal recommended ranges. Although the amount of arsenic found $(0.035 \mathrm{ppm})$ was above the recommended concentration $(0.01 \mathrm{ppm})$ it was below the calculated lethal concentration for most adult fish which is 12 - 20 ppm (Lawrence 1958).

Wood (1974) classified environmental toxic pollutants as (1) non critical, (2) toxic and relatively accessible or (3) toxic but very insoluble or very rare (see Table 1). The majority of the toxic and relatively accessible elements are of the heavy metal and metaloid groups. Arsenic is one of the very toxic and relatively accessible elements.

Arsenic is a known poison and its toxicity to animals is well documented. In drinking water taken over a long period of time a concentration of 0.21 ppm of arsenic has been reported poisonous to humans (Fairhall 1941). Arsenicals form strong bonds with sulfhydryl groups (-SH-), largely in the liver and skin, causing toxicity and accumulation in those tissues. Arsenite, a heavy metal anion, strongly inhibits essential sulfhydryl enzymes such as pyruvate and alpha-keto-gluterate dehydrogenase. Disulfide bonds appear to play an essential role in the polymerization of 
proteins in the mitotic apparatus that form spindle fibers. Reagents that form mercaptides, like arsenic are spindle poisons and also dissolve the isolated mitotic apparatus (Dustin 1963). When a lethal dose of sodium arsenite was given to albino rats, intraperitoneally, death was preceded by a profound fall in body temperature. A smaller dose produced transient hypothermia, with a decrease in response and eventual tolerance. Although the site of action was not studied it seemed likely to have been the hypothalmic temperature regulating center (Norris and Elliot 1945).

Arsenic is made available for organismal uptake by natural. geochemical cycles and microbial action. Arima and Beppu (1964) found an arsenite degradative enzyme induction system in Pseudomonas pseudomallei. A diagram of the biological cycle for arsenic is presented in Figure 2. The toxicity of arsenic depends on the form in which it is found. Almost all naturally occurring forms of arsenic, salts (arsenate; arsenite), oxides (arsenic trioxide), and acids (methylarsenic acid) are very toxic (McKee and Wolf 1963, Wood 1974, Crecelius 1975).

Lawrence (1958) stated that applications of sodium arsenite up to $10 \mathrm{ppm}$ as arsenic trioxide $(7.6 \mathrm{ppm} \mathrm{As})$ were not harmful to fish. However, other studies (Gilderhaus 1966, Hiltebran 1967) indicated that the threshold level was lower than expected. Lawrence (1962, 1966) later reported that two applications of $4.0 \mathrm{ppm}$ sodium arsenite applied one month apart in experimental ponds, reduced the number of bottom organisms an average of 348 and reduced bluegill (L. macrochirus) production an average of 428 as compared with control ponds. Two applications of $8.0 \mathrm{ppm}$ of sodium arsenite applied 
one month apart reduced the number of bottom organisms an average of 458 and bluegili production $65 \%$. An application of $4.0 \mathrm{ppm}$ killed all microcrustacea and greatly reduced the population of rotifers.

Gilderhaus (1966) evaluated the effect of sodium arsenite on adult and immature $\underline{L}$. macrochirus in small fish rearing ponds. In general his experiment demonstrated that applications totaling 4.0 ppm or more of sodium arsenite in one year inhibited the growth of both adults and immatures, and adversely affected the survival of immatures. This $4: 0 \mathrm{ppm}$ concentration was well below the accepted dose of sodium arsenite $\left(2-10 \mathrm{ppm} \mathrm{NaAsO}_{2}=2.5-12.5\right.$ ppm $\mathrm{As}_{2} \mathrm{O}_{3}$ ), which was listed by Lawrence (1958) as an acceptable dose for weed control and which was not harmful to aquatic animals. Hiltebran (1967) found that fry of $\underline{L}$. macrochirus, $\underline{M}$. dolmieui, Erimyzon sucetta, and Compostoma anomalum, were more susceptible to the toxic action of sodium arsenite than were the fertilized eggs or the adults. Other experiments have demonstrated that fishfood organisms are susceptible to concentrations of arsenic as low as 1:0 ppm (Springer 1959, Gilderhaus 1966).

It is apparent from these studies that there are lethal and sublethal effects of arsenic upon adult and immature fish as well as the benthos and microcrustacea (Springer 1959, Gilderhaus 1966, Hiltebran 1967). There have been very few studies in which the effect of sublethal doses of arsenic on newly hatched fish fry have been investigated.

The presence of high concentrations of arsenic in the Pendergast Point hatchery water and the report of Hassan and Spotila 
(1975), on the temperature tolerance of muskellunge fry, suggests. that the mortalities at the hatchery may be due to an interactive effect between rearing temperatures and arsenic contamination. The purpose of this study was to determine the effect of arsenic on the temperature tolerance and survival of newly hatched muskellunge fry. The results reported here may supply information which could provide insight on the hatchery mortality problem. 
MATERIALS AND METHODS

Newly hatched muskellunge fry (Esox masquinongy), were obtained from the Pendergast Point hatchery on May 23, 1975. Approximately 3;000 fry were transported in a sealed plastic bag. at a water temperature of $15^{\circ} \mathrm{C} \pm 0.5^{\circ} \mathrm{C}$. Upon arrival at the laboratory in Buffalo, New York, about 350 fry were immediately transferred to each of eight, 20 liter glass tanks. These tanks contained $17^{\prime}$ liters of aerated, dechlorinated tap water.

six tanks were previously seeded with arsenic, two each at $0.05,1.0$, and $5.0 \mathrm{ppm}$ arsenic. Two tanks served as controls and received no arsenic treatment. Arsenic (As) was used in the form of sodium arsenite $\left(\mathrm{NaAsO}_{2}\right)$, a salt, which has been commonly used as an aquatic herbicide. Arsenic concentrations were checked initially and subsequently analyzed bi-weekly throughout the course of the experiment using flameless atomic absorption spectorphotometry. Analysis was conducted using a Varian Techtron atomic absorption spectrophotometer, by the method of Tam (1974).

Water temperatures were maintained at $15^{\circ} \mathrm{C}\left( \pm 0.5^{\circ} \mathrm{C}\right)$ by placing the experimental tanks in large water baths supplied with heaters, refrigeration coils and thermoregulators. $15^{\circ} \mathrm{C}$ was chosen as the fry acclimation temperature because is approximates the rearing temperature normally used in the past at the Pendergast Point hatchery. Temperatures were measured daily with a mercury thermometer calibrated to $\pm 0.05^{\circ} \mathrm{C}$.

Each glass aquarium was aerated and filtered by a plastic corner filter, filled with activated carbon and glass wool. A photoperiod of 12 hours of light alternating with 12 hours of 
darkness ( $\mathrm{L}: \mathrm{D} 12$ : 12) was centered at 1300 hours E.S.T. Illumination was provided by overhead flourescent lamps. Light intensity was measured with an Epply pyranometer and ranged from $0.01-0.02$ cal $\mathrm{cm}^{-2} \mathrm{~min}^{-1}$. Funk radiometer measurements ranged from 0.01 $0.02 \mathrm{cal} \mathrm{cm}^{-2} \mathrm{~min}^{-1}$. Visible light as measured with a Weston light meter ranged from 68 - 180 foot candles, $\bar{x}=121$ foot candies (Hassan and Spotila 1976).

Tanks were checked daily for dead fry, 'which were removed, rinsed once in distilled water and immediately frozen for future arsenic analysis. After swim-up live brine shrimp (Artemia nauplii) were fed ad. lib. to the fry. Ten fry were sampled bi-weekly from each treatment and also frozen for future analysis.

Water was analyzed bi-weekly for dissolved oxygen (D.O.), pH, alkalinity and ammonia.' A Yellow Springs Instruments (Model \#54) oxygen meter, calibrated using the Azide Modification of the winkler method (Standards Methods 1971), was used to determine D.O.'s. PH was measured using a Fisher $\mathrm{pH}$ Meter (Model 140) which was standardized daily with stock buffer solutions. Ammonia concentrations were measured using the phenate method and alkalinities were determined using the potiometric method (standard Methods 1971). During the first three days of the experiment all tanks were treated with $250 \mathrm{mg}$ of tetracycline to eliminate a saprolegnia sp. infection, which was present in the contol $(0.00 \mathrm{ppm})$ and 0.05 ppm tanks only.

Random samples of six fry from each experimental treatment, were chosen every other day and tested for their thermal tolerance. The thermal tolerance of the fry was checked using the critical 
Thermal Maximum (CTM) method described by Hutchison (1961). A fry was placed into a test water bath at its acclimation temperature and water temperature was raised at a constant rate $\left(1.0^{\circ} \mathrm{C}\right.$ $\min ^{-1} \pm 0.2^{\circ} \mathrm{C}$ ), until the endpoint was reached (see results for description of endpoints used).

Data were statistically analyzed using a one way analysis of variance (one way ANOVA) and graphically using the method of Hutchison (1961). A one way ANOVA was performed on the individual values for the four treatments $(0.00,0.05,1.0,5.0 \mathrm{ppm}$ Arsenic), to determine overall statistical differences between the treatments. Statistical differences between the treatments were also determined using the graphical analysis of Hutchison (1961). Differences in СTM through time in each treatment were analyzed.using a one way ANOVA and graphically using the Hutchison method (1961). Calculated F values were considered significant at the $5 \%$ level of probability $(p=0.05)$ and highly significant at the 18 level $(p=0.01)$. Mortalities were analyzed graphically plotting the time vs. percent dead. 


\section{RESULTS}

Water quality in the experimental tanks remained normal during the course of this experiment (Table 2). Dissolved oxygen ranged from a high of $10.5 \mathrm{mg}^{-1}$ to a low of $8.0 \mathrm{mg} \mathrm{l}^{-1}$. Alkalinity ranged from a low of $149 \mathrm{mg}^{-1}$ of $\mathrm{CaCO}_{3}$ on day one to a high of $190 \mathrm{mg}^{-1}$ on day 15. The $\mathrm{pH}$ fluctuated between 7.2 and 7.7. Tank temperatures remained stable at $15^{\circ} \mathrm{C} \pm 0.5^{\circ} \mathrm{C}$. Ammonia concentrations in all tanks remained below $0.05 \mathrm{mg}^{-1}$.

The endpoint used for the CTM of pre-swim-up fry was the onset of dorsal lateral bending, as described by Hassan and Spotila (1976). This endpoint was clearly exhibited by these fry. More than 908 . of the fry tested in this manner recovered if they were quickly transferred to a $15^{\circ} \mathrm{C}$ water bath. If the fry were taken $1.0^{\circ} \mathrm{C}$ past this endpoint less than 358 recovered. After fry began to swim-up, (day 8) I used the onset of spasms followed by a complete loss of equilibrium as the CTM endpoint. As fry approached their CTM they began to lose their equilibrium and initiated a shuddering movement, the gills became distended and the mouth opened in a gape. I used the rapid shuddering and mouth gaping as the CTM. This was the same endpoint described by Hassan and spotila (1976). All fry recovered from this endpoint if they were placed in a $15^{\circ} \mathrm{C}$ water bath immediately after reaching their endpoint. Some fry underwent a temporary loss of righting response prior to the onset of spasms, but this was transitory and I did not use this as the endpoint. The different endpoints for pre- and post-swim-up fry were used because pre-swim-up fry were 
sessile in nature and did not exhibit muscular control. The sessile nature of pre-swim-up fry warranted the use of a different endpoint.

A one way ANOVA indicated that there was no significant difference in the CTM of fry taken from the two difference experimental tanks within a treatment, therefore the Стм data from these tanks was combined for further statistical analysis. There was a highly significant difference $(p=0.01)$ in the average CTM of muskellunge fry in different treatments (Table 3 ). СтM of the control fry $\left(\overline{\mathrm{X}}=32.42^{\circ} \mathrm{C}\right)$ were significantly higher (Fig. 3) than the $1.0 \mathrm{ppm}\left(\overline{\mathrm{X}}=30.68^{\circ} \mathrm{C}\right)$ and $5.0 \mathrm{ppm}\left(\overline{\mathrm{X}}=30.5^{\circ} \mathrm{C}\right)$ treatments. A graphical comparison of control and $0.05 \mathrm{ppm}$ data indicated that the overall CTM were not significantly different (Fig. 3). This was because the standard error bars overlap slightly. However, a one way ANOVA (Table 4), for these two treatments indicated a significant difference $(p=0.05)$. Thus while the $0.05 \mathrm{ppm}$ treatment did lower the СTM, the statistical significance of this effect was unclear when only the overall values were compared.

There was a highly significant difference $(p=0.01)$ in the CTM of muskellunge fry in all treatments with time (Tables 5, 6, 7 and 8 ). These results are presented graphically in Figures 4 7. There was a significant drop in the CTM of the fry in all treatments during swim-up, but this CTM decrease was more prnounced in the three arsenic treatments when compared to the control. The CTM of the control fry recovered from this sharp drop $\left(32.26^{\circ} \mathrm{C}\right.$ to $30.28^{\circ} \mathrm{C}$ ), and began to slowly increase from $30.28^{\circ} \mathrm{C}$ on day 10 to 
$31.78^{\circ} \mathrm{C}$ on day 15 (Fig. 4). The CTM of all arsenic treated fry remained low and never recovered from the initial drop in CTM (Figs. 5 - 7). C.T.M of the $0.05 \mathrm{ppm}$ fry dropped from $32.5^{\circ} \mathrm{C}$ on day 8 to $28.36^{\circ} \mathrm{C}$ on day 15 (Fig. 5). A similar pattern occurred for the 1.0 and 5.0 ppm tanks (Figs. 6, 7). The CTM for fry in all arsenic treatments continued to drop until day 15 when all fry in these treatments were dead. The swim-up period was prolonged in the tanks treated with arsenic. Mortality curves (Figs. 8 - 11), show that all the arsenic. treated fry died by day 15 of the experiment, which was seven days after the onset of swim-up. The control fry survived the experiment and had a low mortality until day 25, at which time the experiment was terminated due to a lack of sufficient live food. The mortalities for the fry in the arsenic treatments was low for the initial eight days but after the onset of swim-up there was a minimum of three times the average daily mortality increase in fry deaths. This increase in fry mortalities continued until day 15 when 1008 of the arsenic treated fry were dead. The mortality curves indicate that the fry died more rapidly in the higher arsenic concentrations than the lower arsenic concentrations.

An attempt was made using atomic absorption analysis, to determine if there was any arsenic present in the eggs and fry prior to the experiment and to determine if any uptake or concen-. tration of arsenic occurred in the fry during the course of this experiment. However all digestion processes attempted were ineffective due to high lipid concentrations in the eggs and fry. The lipids violently reacted with the zinc slurry and caused so much interference, that arsenic readings were not possible. 


\section{DISCUSSION}

Arsenic has a significant effect on the temperature tolerance and survival of muskellunge fry. It has been demonstrated that a significant drop in CTM occurs in muskellunge fry (Hassan and spotila 1976), during swim-up. In this experiment the control fry were the only group to survive the experiment and recover from the characteristic decrease in CTM that occurred during. swimup. Arsenic prolongs and pronounces this CTM decrease during swim-up. The thermal tolerance of the fry was altered by the presence of arsenic and a 1008 mortality of the fry occurred in all arsenic treatments.

The higher arsenic concentration (5.0 ppm) caused a more pronounced decrease in CTM at swim-up and more rapid mortalities than the lower concentrations $(1.0$ and $0.05 \mathrm{ppm})$. The $5.0 \mathrm{ppm}$ group had the lowest overall CTM $\left(30.5^{\circ} \mathrm{C}\right)$ followed by $1.0 \mathrm{ppm}$ $\left(30.68^{\circ} \mathrm{C}\right), 0.05 \mathrm{ppm}\left(31.54^{\circ} \mathrm{C}\right)$ and the control group $\left(32.42^{\circ} \mathrm{C}\right)$. The death rate was most rapid in the $5.0 \mathrm{ppm}$ group, followed by 1.0 and 0.05 ppm, all these groups eventually having lo0\% mortality by day 15. The effects of arsenic on the fry were increased with an elevation in the concentration of arsenic in the water.

The results indicate that the accepted arsenic herbicide treatment value, 2 - 10 ppm (Lawrence 1962), would affect the thermal tolerance and survival of immature muskellunge. In fact the levels of arsenic reported at Chautauqua Lake by Lis and Hopke (1973) may be lethal to muskellunge fry. Wood (1974) described how arsenic acts like mercury in the aquatic ecosystem in several 
ways. He diagramed the biological cycle for arsenic (Fig. 2), which illustrates how arsenic remains in and recycles within the aquatic ecosystem. The immatures of subsequent generations could be affected by the continual release of arsenic from the sediments.

In light of the results of this study and other recent findings (Gilderhaus 1966, Hiltebran 1967, Cairns et al. 1975), it appears that present treatment values for all toxic chemicals should be re-evaluated. The existing standards were determined when accurate modern analytical equipment was not available. Many standard values were also determined using hardy adult indicator organisms such as bluegills (ㄴ. macrochirus), and bass (Micropterous sp.). The effect of toxins on immature fish could be very important to the stability of an aquatic ecosystem. Thus the tolerance of immature fish should be considered in the determination of new standards for heavy metals.

Since the swim-up period of development has been demonstrated to be stressful and critical in the morphogenesis of the muskellunge, any additional stress, such as that caused by arsenic pollution can be lethal. The results of this study lend support to the idea that immatures are less tolerant, of toxicants and more susceptible to environmental perturbations than adults. These results are consistent with other fish studies which demonstrated that immature fish are less tolerant of toxic chemicals than adults (Gilderhaus 1966, Hiltebran 1967, Nimi and LaHam 1975).

The report of Hassan and Spotila (1976) and this study suggests that the mortalities at the Chautauqua Lake hatchery may be due to an interactive effect of rearing temperature and arsenic 
contaminations. I suggest that the New York State Department of Environmental Conservation further investigate the possibility of arsenic contaimination in the hatchery well water. The interactive effect of rearing temperatures and heavy metal contamination in the survival of muskellunge fry should also be investigated. 
Table 1. Classification of elements according to their toxicity, after Wood (1974).

\begin{tabular}{|c|c|c|c|c|c|c|c|}
\hline \multicolumn{3}{|c|}{ Noncritical } & \multicolumn{3}{|c|}{$\begin{array}{c}\text { Very Toxic } \\
\text { and relatively } \\
\text { accessible }\end{array}$} & \multicolumn{2}{|c|}{$\begin{array}{l}\text { Toxic but } \\
\text { very insoluble } \\
\text { or very rare }\end{array}$} \\
\hline $\begin{array}{l}\mathrm{Na} \\
\mathrm{K} \\
\mathrm{Mg} \\
\mathrm{Ca} \\
\mathrm{H} \\
\mathrm{O} \\
\mathrm{N}\end{array}$ & $\begin{array}{l}\mathrm{C} \\
\mathrm{P} \\
\mathrm{Fe} \\
\mathrm{S} \\
\mathrm{C} 1 \\
\mathrm{Br}\end{array}$ & $\begin{array}{l}\mathrm{F} \\
\mathrm{L} i \\
\mathrm{Rb} \\
\mathrm{Sr} \\
\mathrm{A} 1 \\
\mathrm{Si}\end{array}$ & $\begin{array}{l}\mathrm{Be} \\
\mathrm{Co} \\
\mathrm{Ni} \\
\mathrm{Cu} \\
\mathrm{Zn} \\
\mathrm{Sn}\end{array}$ & $\begin{array}{l}\text { As } \\
\mathrm{Se} \\
\mathrm{Te} \\
\mathrm{Pd} \\
\mathrm{Ag} \\
\mathrm{Cd}\end{array}$ & $\begin{array}{l}\mathrm{Au} \\
\mathrm{Hg} \\
\mathrm{Pb} \\
\mathrm{Sb} \\
\mathrm{Bi} \\
\mathrm{Pt}\end{array}$ & $\begin{array}{l}\mathrm{Ti} \\
\mathrm{Hf} \\
\mathrm{Zr} \\
\mathrm{W} \\
\mathrm{Nb} \\
\mathrm{Ta} \\
\mathrm{Re}\end{array}$ & $\begin{array}{l}\mathrm{Ga} \\
\mathrm{La} \\
\mathrm{Os} \\
\mathrm{Rh} \\
\mathrm{Ir} \\
\mathrm{Ru} \\
\mathrm{Ba}\end{array}$ \\
\hline
\end{tabular}


Table 2. Water quality for tanks used in the arsenic study. Values are given as ranges.

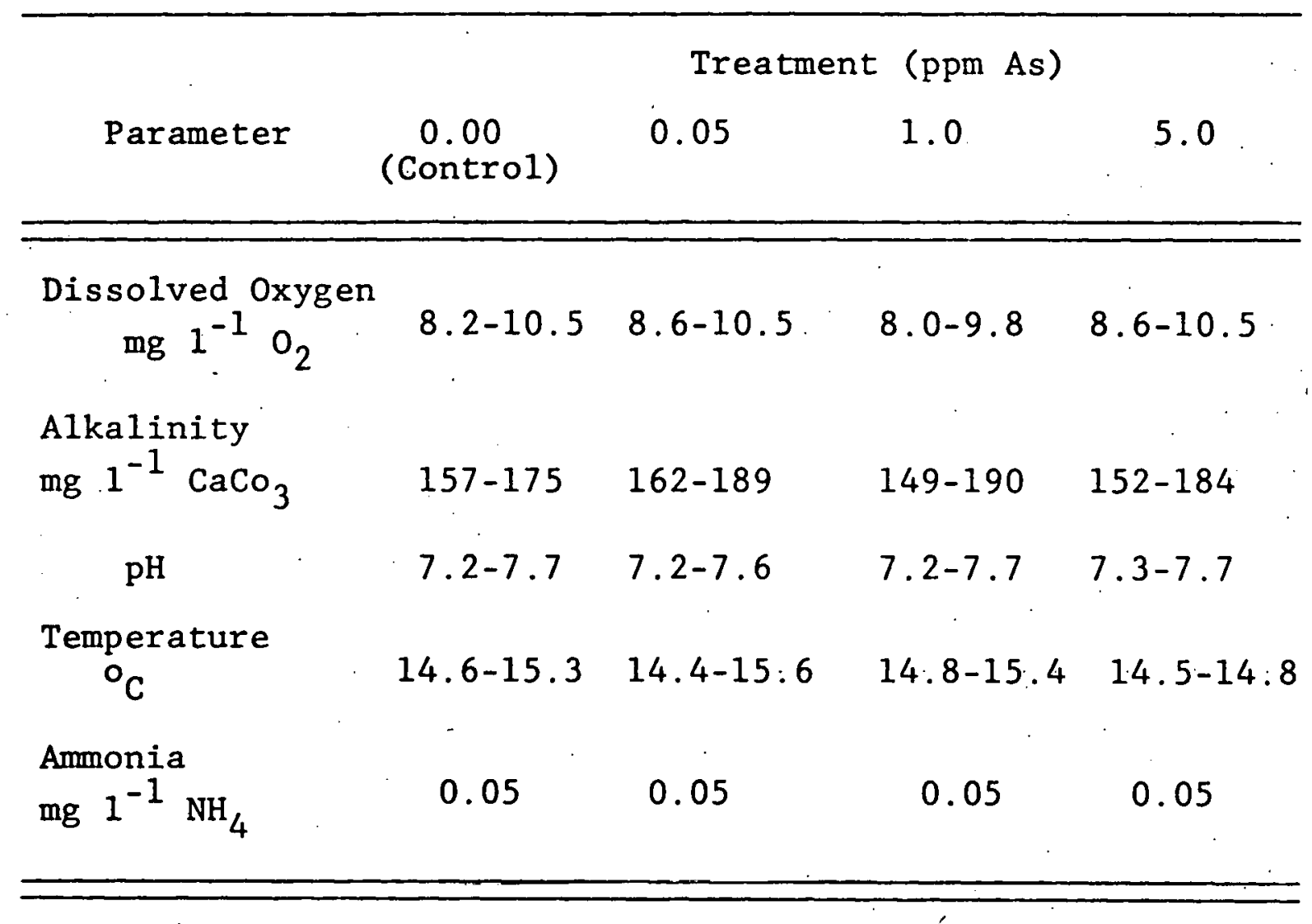


Table 3. One Way ANOVA for overall CTM of muskellunge fry reared in 0.00 (Control) $0.05,1.0$ and $5.0 \mathrm{ppm}$ arsenic.

\begin{tabular}{|c|c|c|c|c|}
\hline SOURCE & $d f$ & SS & MS & F \\
\hline $\begin{array}{l}\text { Between Means } \\
\text { Within Means } \\
\text { Total }\end{array}$ & $\begin{array}{r}3.0 \\
176.0 \\
179.0\end{array}$ & $\begin{array}{l}104.77 \\
846.6 \\
951.38\end{array}$ & $\begin{array}{r}34.9 \\
4.8 \\
0.0\end{array}$ & $7.26 * *$ \\
\hline
\end{tabular}

Table 4. One Way ANOVA for CTM of muskellunge fry reared in 0.00 (Control) and $0.05 \mathrm{ppm}$ arsenic.

\begin{tabular}{lrrrr}
\hline SOURCE & df & SS & MS & F \\
\hline Between Means & $\begin{array}{rrr}1.0 \\
86.0\end{array}$ & $\begin{array}{r}18.03 \\
280.20\end{array}$ & $\begin{array}{r}18.03 \\
3.26\end{array}$ & 5.54 ** \\
$\begin{array}{l}\text { Within Means } \\
\text { Total }\end{array}$ & 87.0 & 298.23 & 0.00 & \\
\hline
\end{tabular}

${ }_{* \mathrm{P}}=.05$

$\star \star P=.01$ 
Table 5. One Way ANOVA for CTM through time of muskellunge fry reared in $0.00 \mathrm{ppm}$ arsenic (Control).

\begin{tabular}{lrrrr}
\hline SOURCE & df & SS & MS & F \\
\hline & & & \\
\hline $\begin{array}{l}\text { Between Means } \\
\text { Within Means }\end{array}$ & $\begin{array}{r}7.0 \\
\text { Total }\end{array}$ & $\begin{array}{r}217.63 \\
41.0\end{array}$ & $\begin{array}{r}31.09 \\
1.08\end{array}$ & $7.61 * *$ \\
& & & 0.00 & \\
\hline
\end{tabular}

Table 6. One Way ANOVA for CTM through time of muskellunge fry reared in $0.05 \mathrm{ppm}$ arsenic.

\begin{tabular}{lrrrr}
\hline SOURCE & df & SS & MS & F \\
\hline \hline & & & \\
\hline $\begin{array}{l}\text { Between Means } \\
\text { Within Means }\end{array}$ & $\begin{array}{r}7.0 \\
\text { Total }\end{array}$ & $\begin{array}{r}168.23 \\
17.34\end{array}$ & $\begin{array}{r}24.03 \\
.46\end{array}$ & $52.66 * *$ \\
\hline
\end{tabular}

$\begin{aligned} * \mathrm{P} & =.05 \\ \star * \mathrm{P} & =.01\end{aligned}$ 
Table 7. One Way ANOVA for CTM through time of muskellunge fry reared in 1.0 ppm arsenic.

\begin{tabular}{lrrrr}
\hline SOURCE & df & SS & MS & F \\
\hline & $\begin{array}{rrr}7.0 \\
\text { Between Means }\end{array}$ & $\begin{array}{r}217.63 \\
41.35\end{array}$ & $\begin{array}{r}31.09 \\
1.08\end{array}$ & $28.57 * *$ \\
$\begin{array}{l}\text { Within Means } \\
\text { Total }\end{array}$ & 45.0 & 258.98 & 0.00 & \\
\hline
\end{tabular}

Table 8. One Way ANOVA for CTM through time of muskellunge fry reared in 5.0 ppm arsenic.

\begin{tabular}{|c|c|c|c|c|}
\hline SOURCE & $d f$ & SS & MS & $\mathrm{F}$ \\
\hline $\begin{array}{l}\text { Between Means } \\
\text { Within Means } \\
\text { Total }\end{array}$ & $\begin{array}{r}7.0 \\
38.0 \\
45.0\end{array}$ & $\begin{array}{r}249.64 \\
57.27 \\
306.91\end{array}$ & $\begin{array}{c}35.66 \\
1.5 \\
0.00\end{array}$ & $23.66 * x$ \\
\hline
\end{tabular}

$\begin{aligned} * P & =.05 \\ \star * P & =.01\end{aligned}$ 
op. 21

Figure 1. Outline map of Chautauqua Lake, New York. 


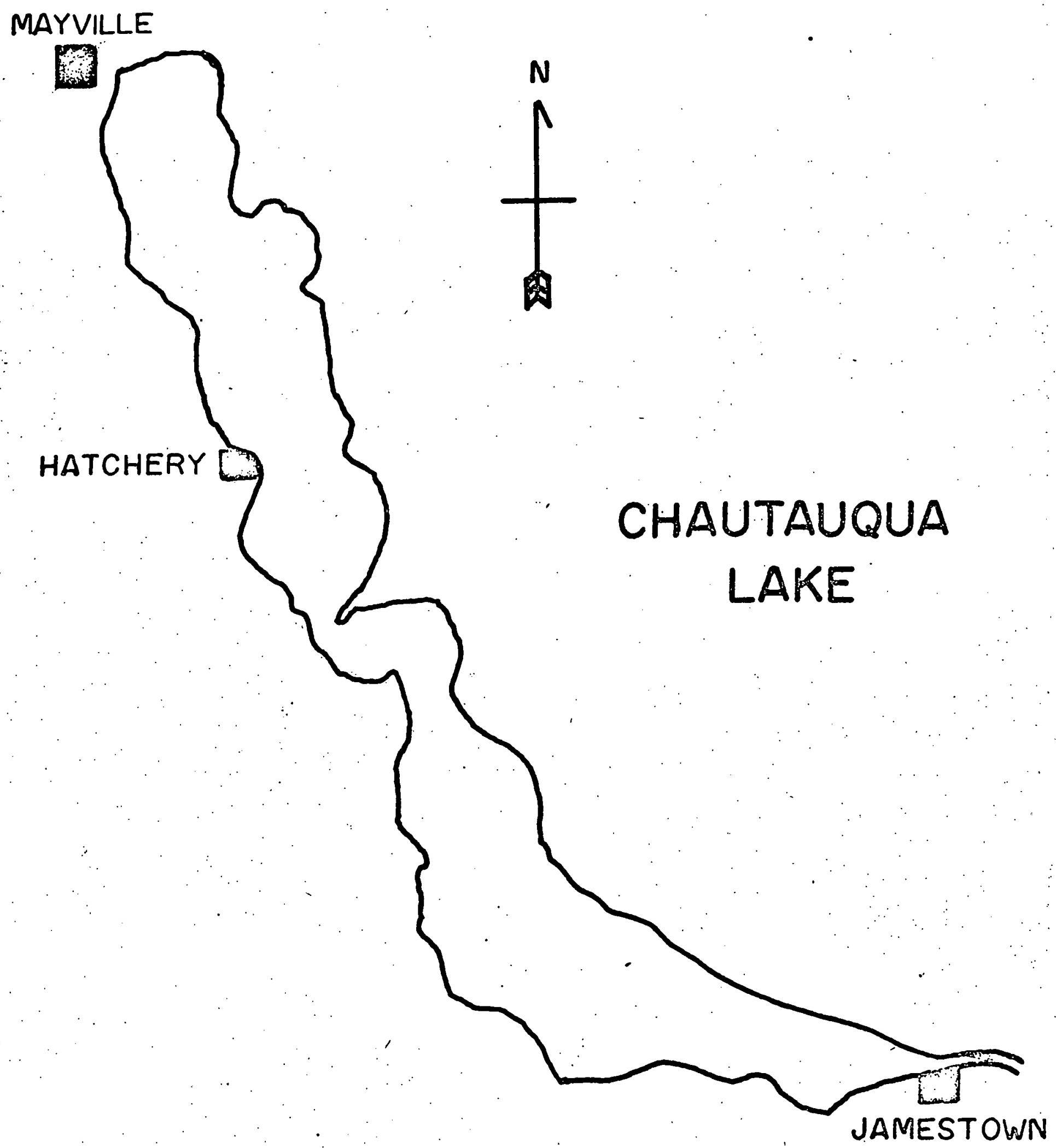


op. 22

Figure 2. The biological cycle for arsenic redrawn after Wood (1974). 


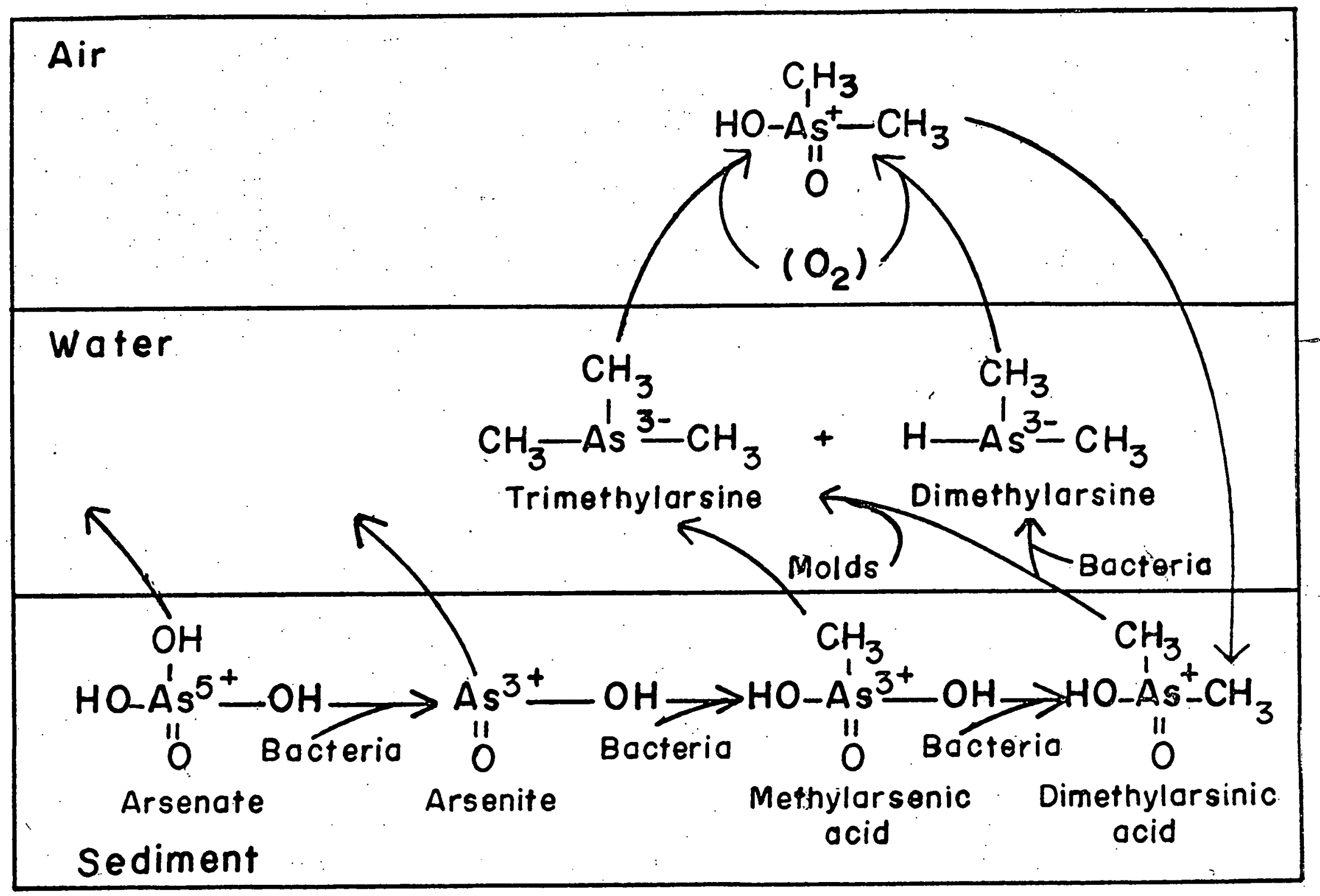

The biological cycle for arsenic 
Figure 3: Graphical comparison of the overall CTM for muskellunge fry reared in 0.00 (control), 0.05 , 1.0 and $5.0 \mathrm{ppm}$ arsenic. Center verticle lines represent overall treatment CTM mean, open rectangles represent 2 standard errors to either side of the mean, Sample size was 45 for each treatment. If open rectangles of the different treatments overlap then they are non-significant $\mathrm{p}=0.05$. After method of Hutchison (1961). 


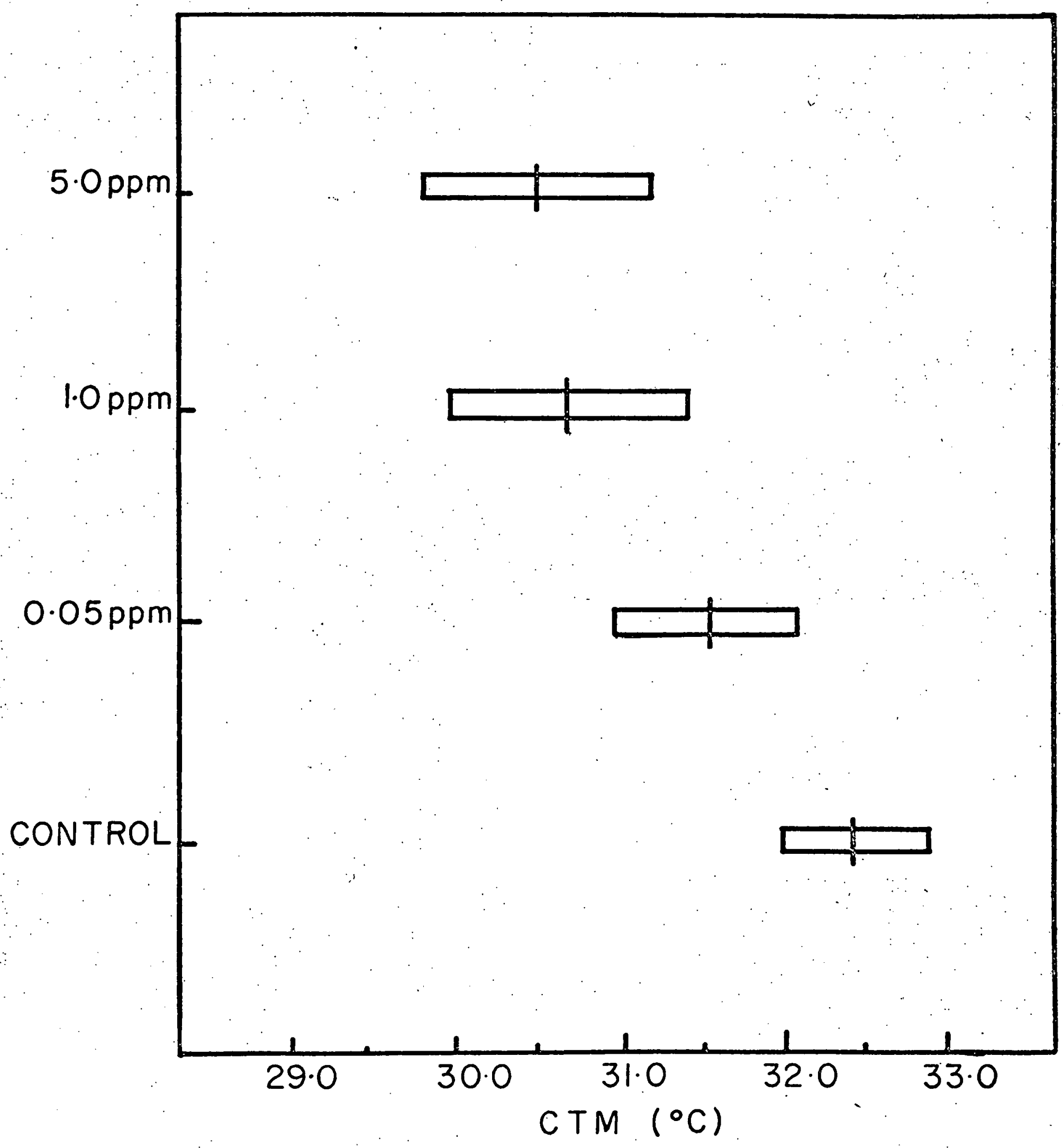


op. 24

Figure 4. CTM through time of muskellunge fry reared in 0.00 $\mathrm{ppm}$ arsenic (control). Verticle lines bounded by short horizontal lines represents the range, median horizontal line represents mean and black rectangles represent 2.54 standard errors to either side of the mean. Sample size was 6 . If the black rectangles for the CTM of different days overlap then they are non-significant $\mathrm{p}=0.05$. After method of Hutchison (1961). 


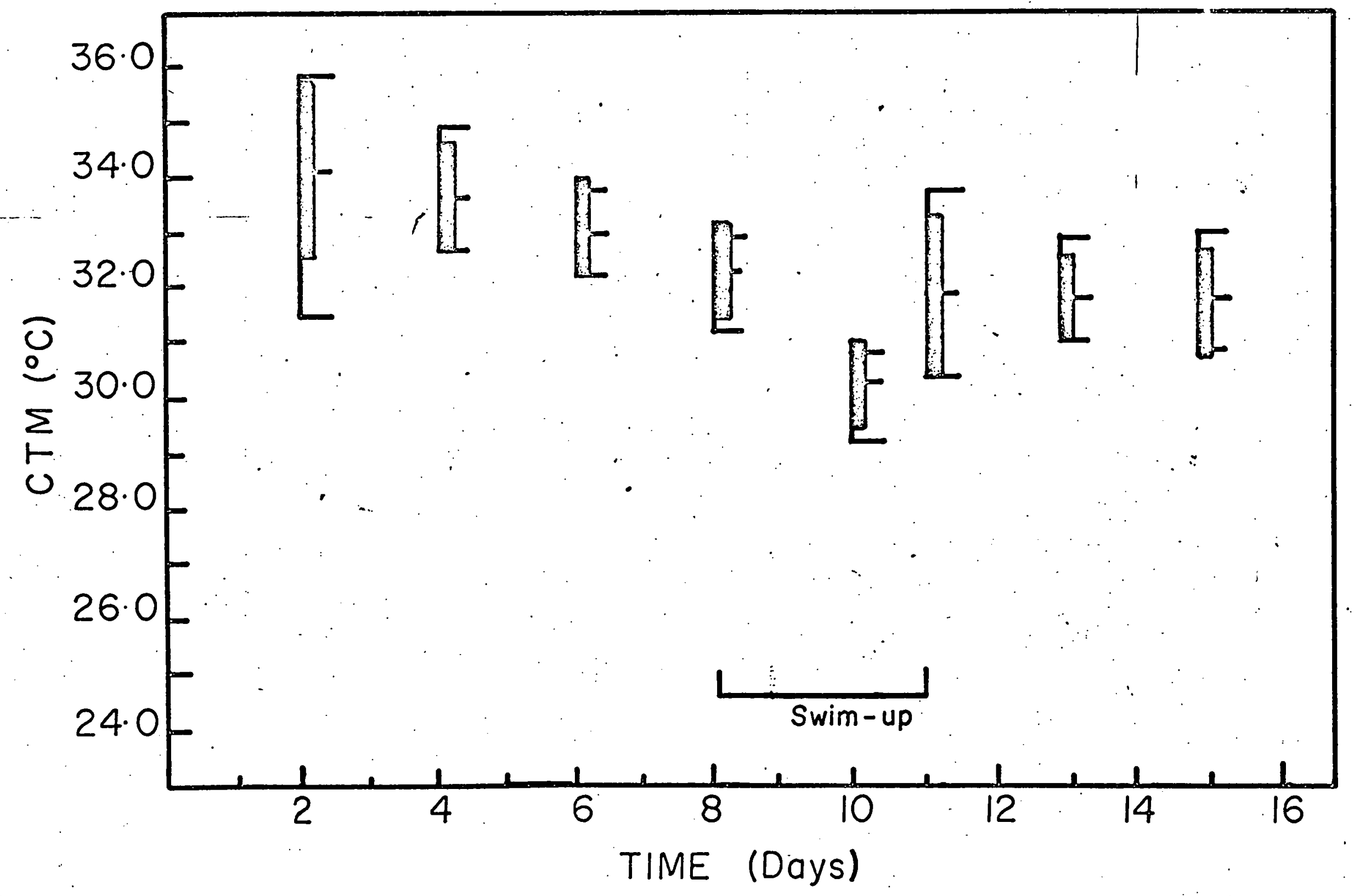


op. 25

Figure 5. CTM through time of muskellunge fry reared in 0.05 ppm arsenic. See Figure 4 for explaination of graph. 


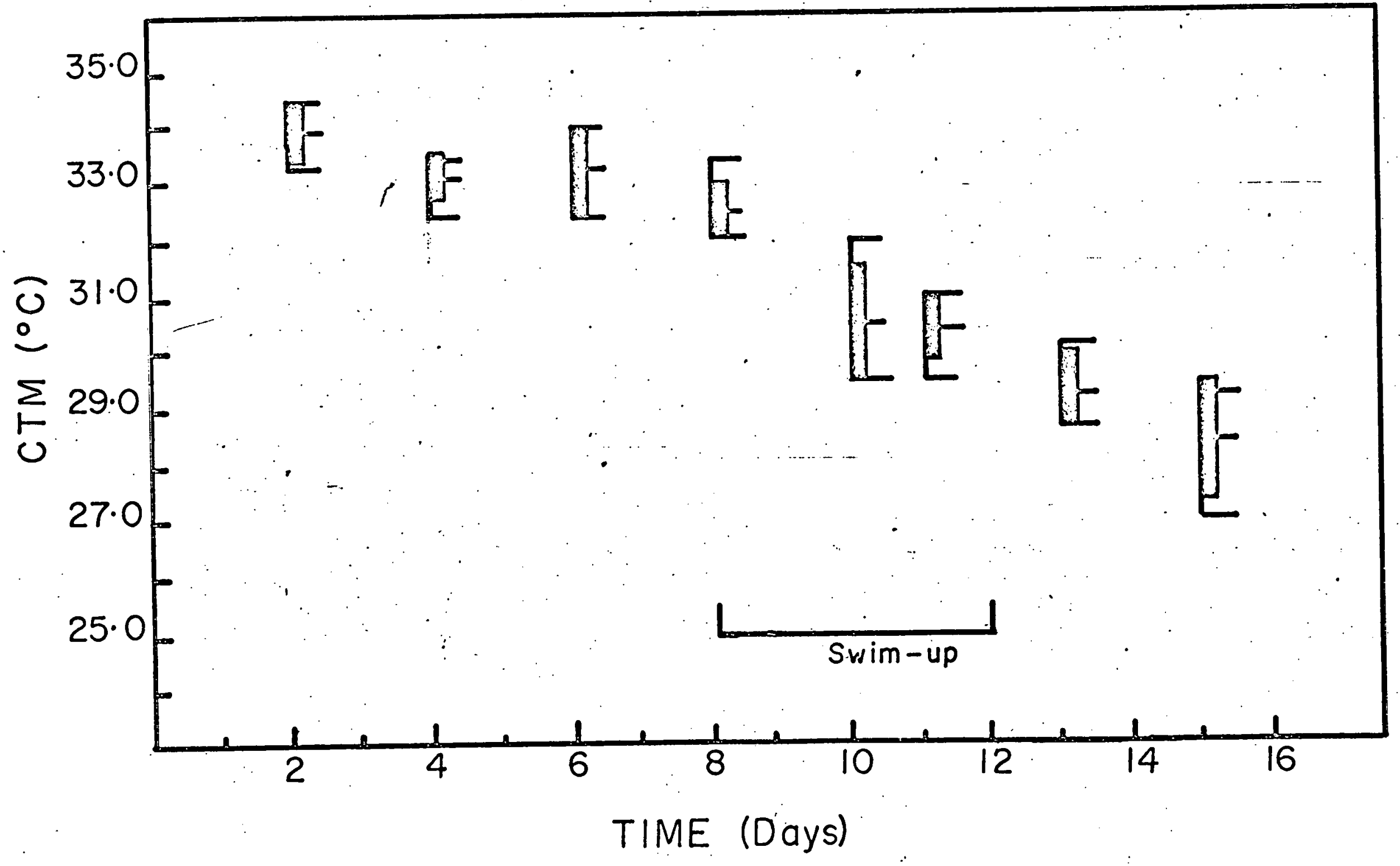


op. 26

Figure 6. CTM through time of muskellunge fry reared in 1.0 ppm arsenic. See Figure 4 for explaination. 


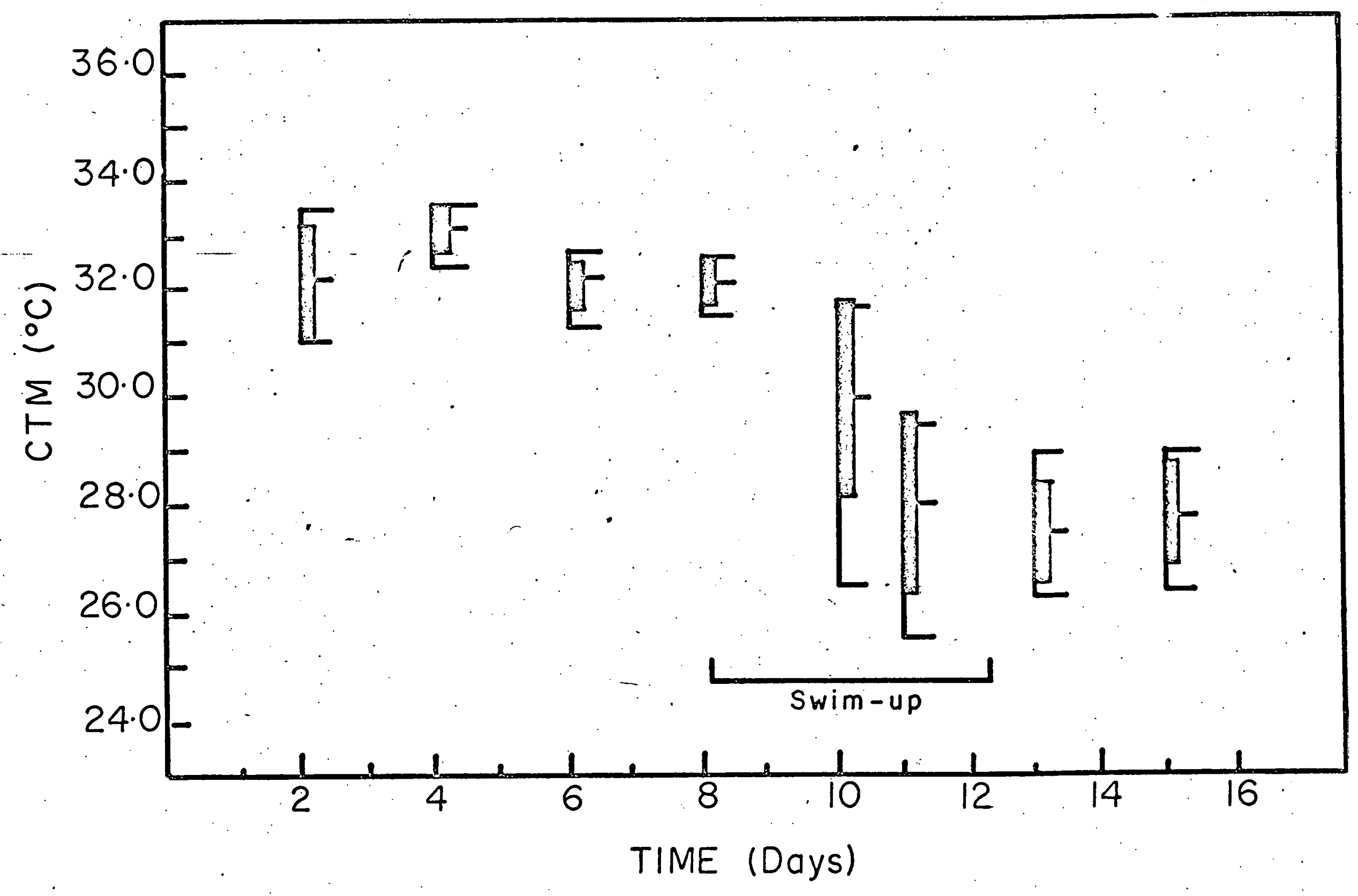


op. 27

Figure 7. CTM through time of muskellunge fry reared in 5.0 ppm arsenic. See Figure 4 for explaination. 


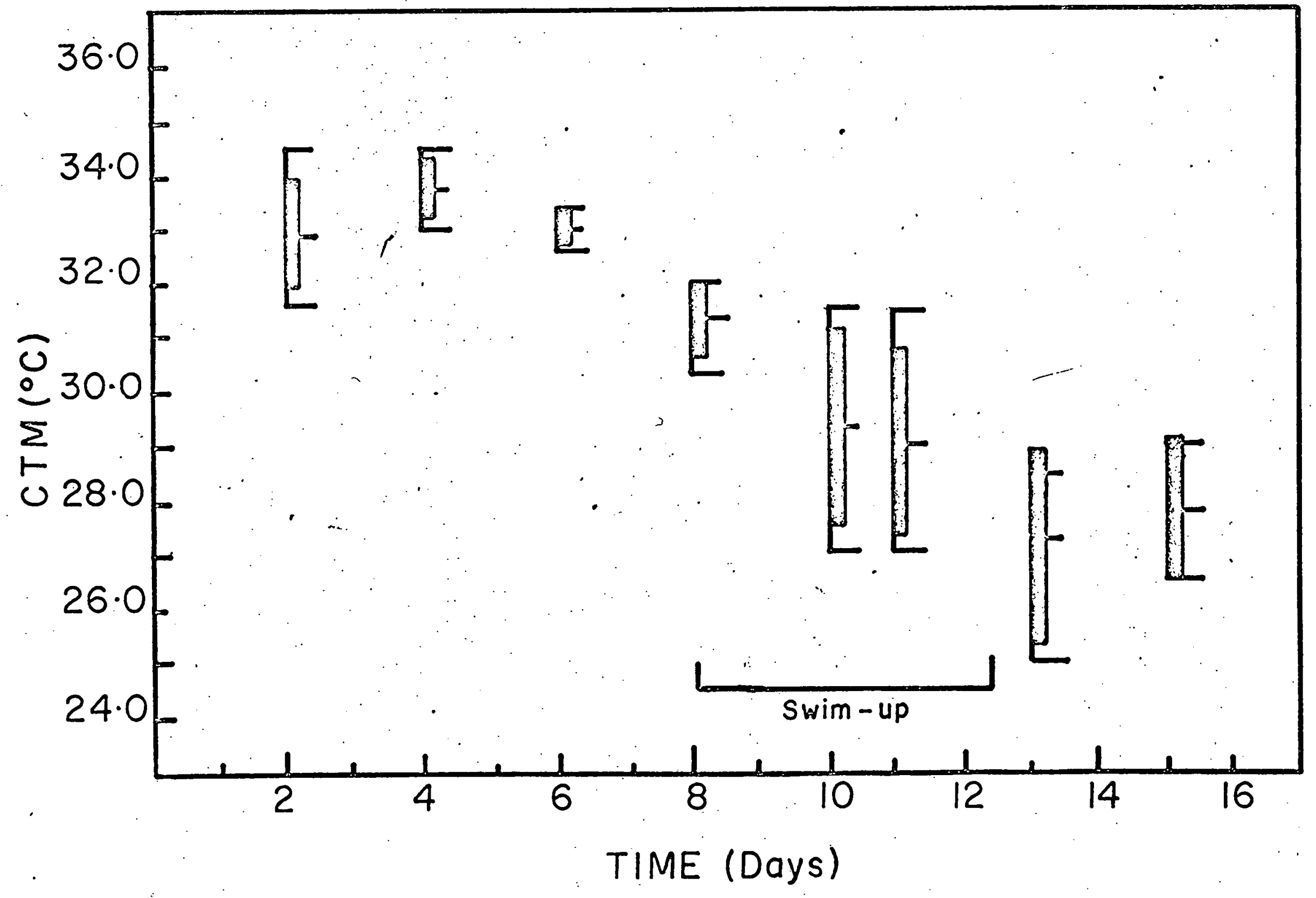


op. 28

Figure 8. Daily mortality (percent dead) through time of muskellunge fry reared in $0.00 \mathrm{ppm}$ arsenic (Contro1). 


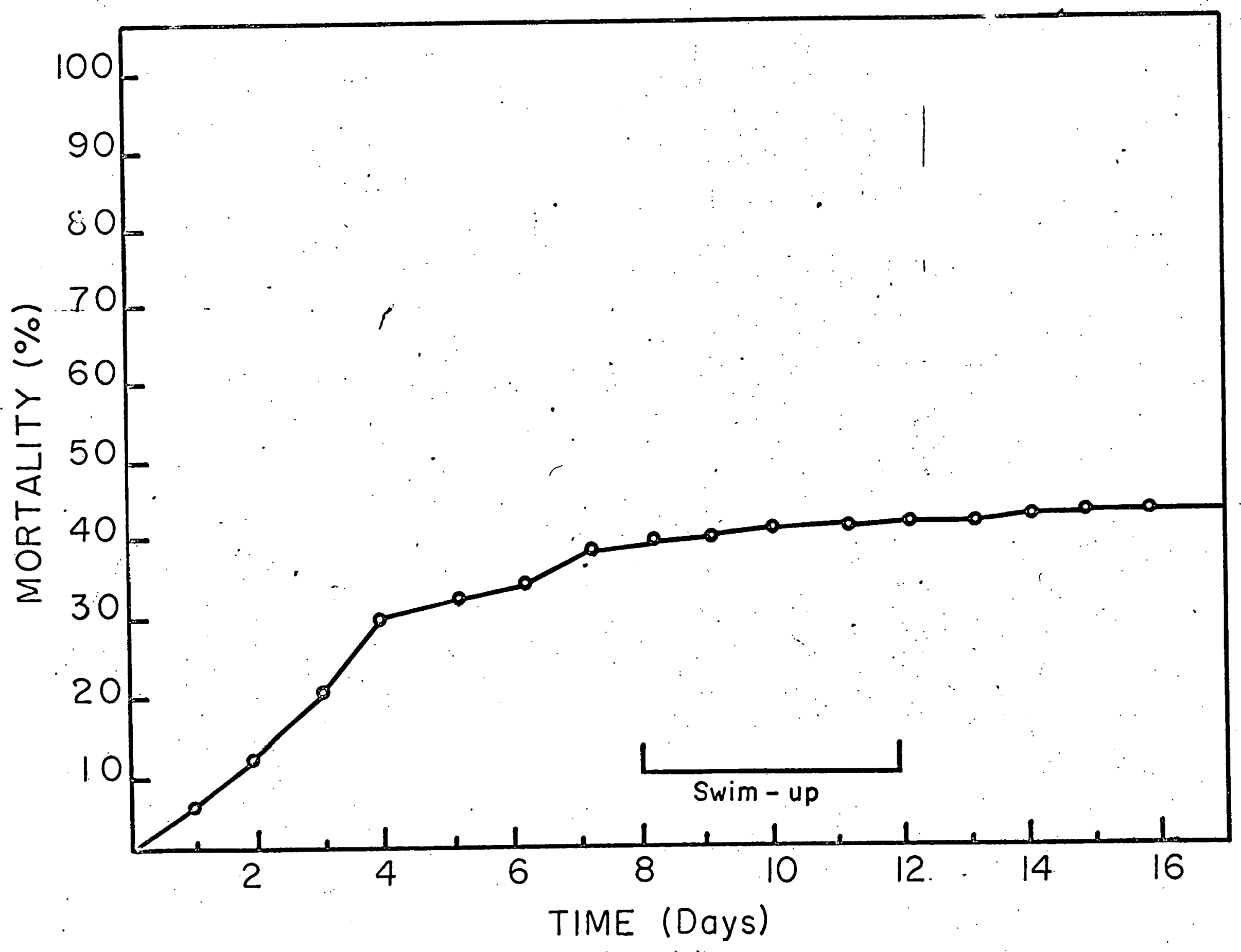


op. 29

Figure 9. Daily mortality (percent dead) through time of muskellunge fry reared in $0.05 \mathrm{ppm}$ arsenic. 


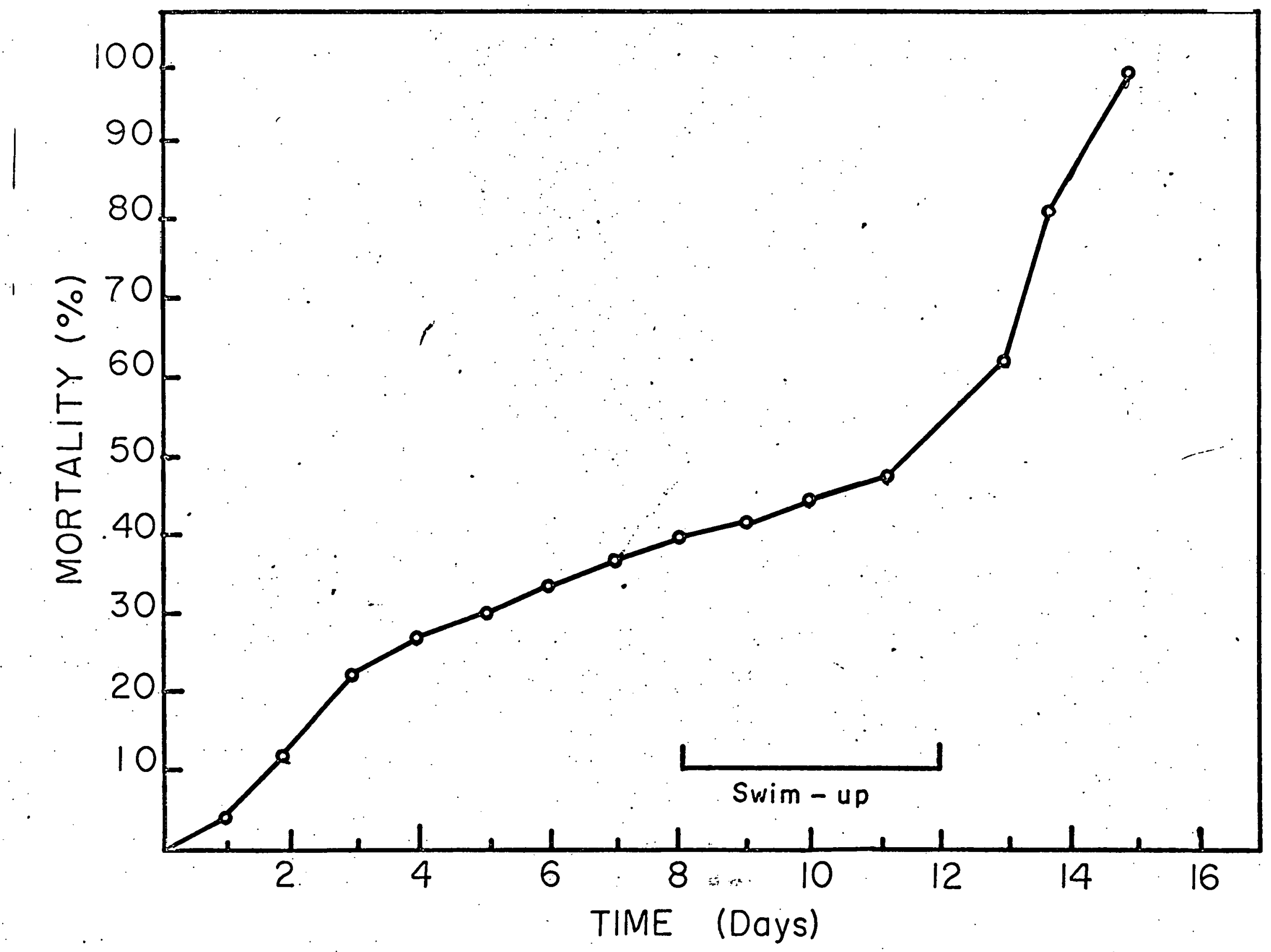


op. 30

Figure 10. Daily mortality (percent dead) through time of muskellunge fry reared in $1.0 \mathrm{ppm}$ arsenic. 
op. 31

Figure 11. Daily mortality (percent dead) through time of muskellunge fry reared in $5.0 \mathrm{ppm}-$ rsenic. 


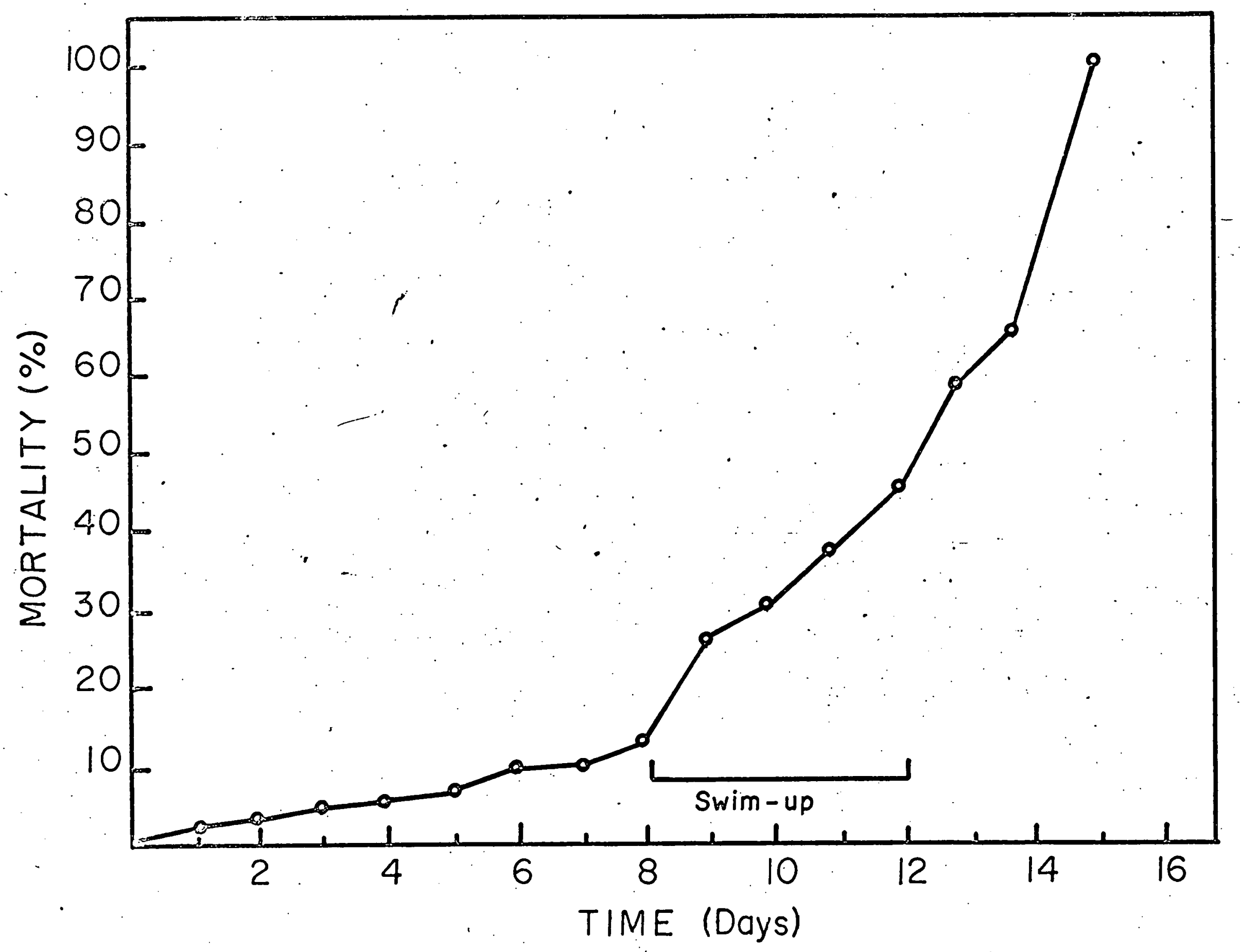




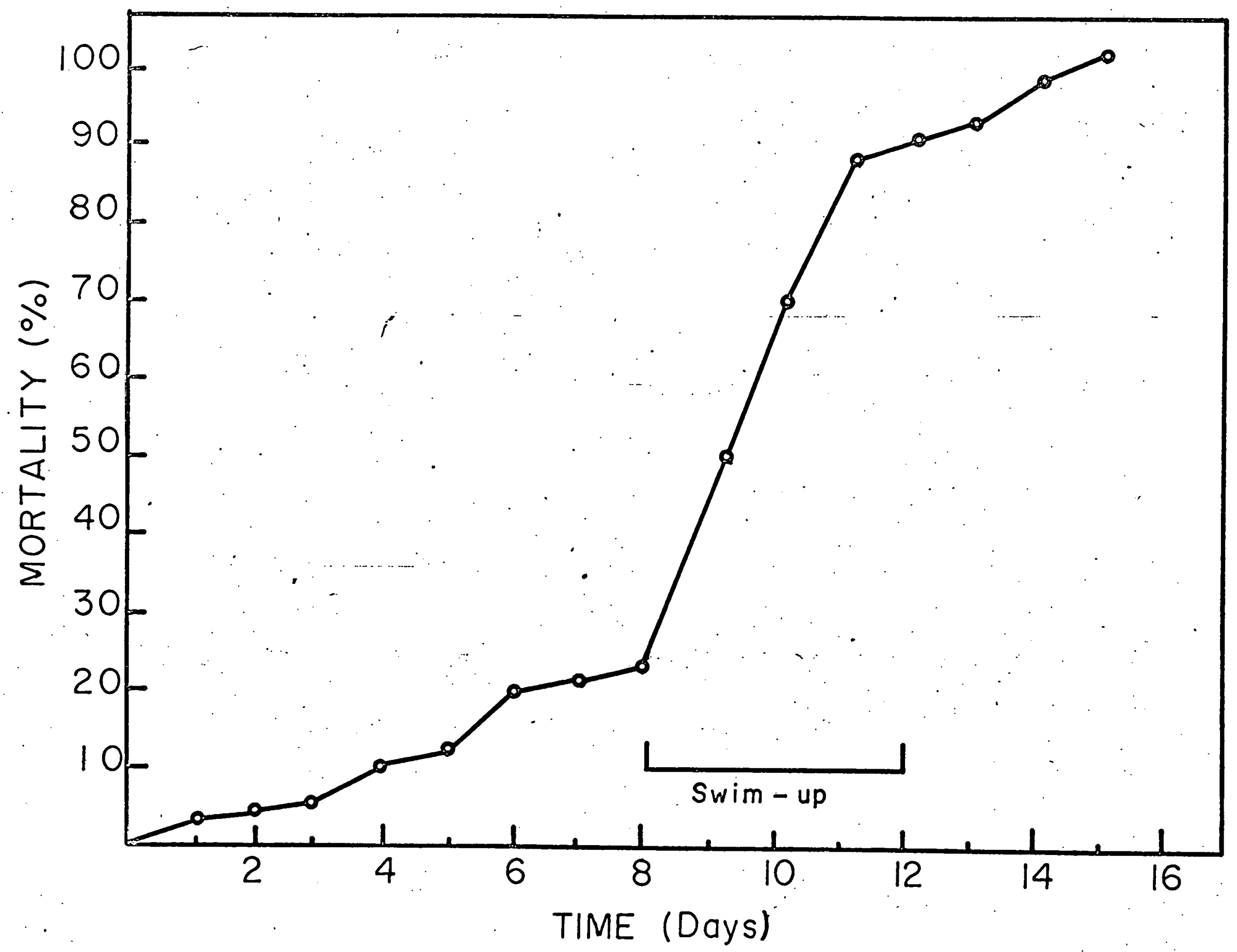


LITERATURE CITED

Arima and Beppu. 1964. Induction and mechanisms of arsenite resistance in pseudomonas pseudomallei. J. Bacteriol. 88:143.

Banner, A. and J. Van Arman. 1973. Thermal effects on eggs, larvae and juveniles of bluegill sunfish. Report: Ecological Research Series EPA R-3-73-041, 7p.

Beal, 1975. Selenium determination on fish tissue. J. Fish. Res. Bd. Can. 32:249-252.

Brett, J. 1956. Some principles in the thermal requirements of fishes. Quart. Rev. Bio. 31:7.5-87.

Cairns, J. and A. Schneirer. 1957. The effects of temperature and hardness of water upon the toxicity of zinc to the common bluegill. Not. Nat. Acad. Nat. Sci. Phil. \#299. 8p.

- 1959. The effects of temperature and hardness upon the toxicity of potassium dichromate to common bluegill sunfish. Trans. of.N.E. Wildlife Conf. 1959. pp. 86-89.

- 1964. The effects of sublethal levels of zinc and of high temperature on the toxicity of a detergent to the sun fish Lepomis gibbosus. Not. Nat. Acad. Nat. Sci. Phil. \#367 June 1964. 12p.

Cairns, J., A. Heath, and B. Parker. 1975. The effects of temperature upon the toxicity of chemicals to aquatic organisms. Hydrobiologia $47: 135-171$.

Crecelius, E. 1975. Arsenic geochemical cycle in Lake Washington and its relation to other elements. Iimnol. Oceanogr. In Press.

Douderoff, P., B. Anderson, G. Burdick, P. Galtsoff, W. Hart, R. Patrick, E. Strong, E. Surber, and W. Van Horn. 1951. Bioassay methods for the evaluation of acute toxicity of industrial wastes to fish. Sewage and Industrial Wastes, 23:1390-1397.

Dupree, H. 1960. The arsenic content of water, plankton, soil and fish from ponds treated with sodium arsenite for weed control. Proceedings of the 14 th Annual Conf. S. E. Assoc. of Game and Fish Comm. pp. 132-136.

Dustin, 1963. New aspects of the pharmacology of anti mitotic agents. Pharmacol. Rev. 15:449.

Fairhall, I. 1941. Toxic contaminants of drinking water. N.E. Wild. Wa. $55: 440$.

Gilderhaus, P. 1966. Some effects of sublethal concentration of 
sodium arsenite on bluegills and the aquatic environment. Trans. Amer. Fish. Soc. 95:289-296.

Hart, W., P. Douderoff and J. Greenbank. 1945. The evaluation of the toxicity of industrial wastes, chemicals and other substances to fresh water fishes. Special Publication Atlantic Refining Co. Phil. Pa. \#317. 24p.

Hassan, K. and J. Spotila. 1976. The effect of acclimation on the temperature tolerance of your muskellunge fry. Thermal Ecology Vol. II MCFarlane and Esch (eds.) In Press.

Hiltebran, R. 1967. Effects of some herbicides on fertilized fish eggs and fry: Trans. Amer. Fish. Soc. 96:414-416.

Hopke, P., Ruppert, Clute, Metzger, Growley. 1974. Arsenic concentrations and distribution in Chautauqua Lake sediments. J. of Radioanal. Chem. 23:159-169.

Hokanson, K., J. McCormick, and B. Jones. 1973. Temperature regulation for embryos and larvae of the northern pike. Trans. Amer. Fish. Soc. 102:89-100.

Hutchison, V. 1961. Critical Thermal Maxima in salamanders. Phys. Zool. 34:92-105.

Johnson, D. 1968. Pesticides and fishes - a review of selected literature. Trans. Amer. Fish: Soc. 97:398-424.

Lawrence, J. 1958. Recent investigations on the use of sodium arsenite as an algacide and its effects on fish production in ponds. Proceedings of the 11th Ann. Conf. S.E. Assoc. of Fish. Comm. pp. 281-287.

- 1962. Aquatic herbicide data U. S. Department of Agricul. Handbook \#231 pp. 848-876.

- 1966. Aquatic weed control in fish ponds. Proc. of the World Symp. on Warm Water Fish. Cult. Rome, Italy. May 1966 FAO Fish Rep \#44 5:71-96.

Lis, S. and P. Hopke. 1973. Anaomalous arsenic concentrations in Chautauqua Lake. Environ. Let. 5:45-52.

McKee, J. and Wolf. Editors. 1963. State of California Water Qual. Criteria. Sacramento, Calif. pp. 140-1, 260-2.

Nicholson, S. 1974. Personal Communication. Assistant Professor of Biology, State University College at Fredonia, NY

Nimi, A. and Q. LaHam. 1975. Selenium toxicity on the early stages of zebrafish (Brachydanio rerio). J. Fish. Res. Bd. of Can. 32: 803-806. 
Norris and Elliott. 1945. Tolerance to arsenic trioxide in the albino rat. Amer. J. Physiol. 143:635.

Springer, P. 1959: Report of the research coordinating committee category aquatics. Supplement to Proc. 13 th Ann. Meet. N.E. Weed Cont. Conf. 17p.

Standards Methods for the Examination of Water and Wastewater Thirteenth Edition: M. Taras, A. E. Greenberg, R. Hoak and M. Rand (eds:) American Public Health Association Publication 1971 .

Surber E. 1932. Controlling vegetation in fish ponds. with sodium aresenite. U. S. Bur. of Fish. Invest. Rep. 11:33 pp.

Tam, K. 1974. Arsenic in water by flameless atomic absorption spectrophotometry. Environ. Sci. and Tech. 8:734.

Ullman, W., R. Schaefer' and W. Sanderson. 1961. Arsenic accumulation by $f$ ish in lakes treated with sodium arsenite. J. Water Poll. Cont. Fed. 33:416-418.

Uthe, J. and E. Bligh. 1971. Preliminary survey of heavy metal contamination of Canadian freshwater fish. J. Fish. Res. Bd. Can. $28: 786-788$.

Wood, J. 1974. Biological cycles for toxic elements in the environment Science Mar. 15, 188:1049-52.

Yeomans, N. 1974. Personal Communication. Director of Pendergast Point muskellunge hatchery. 


\section{BIOGRAPHICAL SKETCH OF AUTHOR}

Frank Vincent Paladino

completed his undergraduate education in June 1974

at the State University College at Plattsburgh, New York. receiving a Bachelor of Arts degree in Biology. As an undergraduate the author was a New York State Regents Scholarship recipient and a resident assistant in the residence halls.

The author entered the Master of Arts program in Biology at the State University College at Buffalo in September 1974. During his first semester he was a teaching assistant in the Department of Psychology. He was subsequently supported as a residence hall director by the Office of Residence Life. The author was married to Jacqueline Ann Corral on December 27, 1974. They are the parents of one son Michael Frank, born on December 7. 1975.

Commencing in August, 1976 the author will be a doctoral student in the Department of Zoophysiology at Washington State University in Pullman, Washington. 